\title{
Folate promotes $S$-adenosyl methionine reactions and the microbial methylation cycle and boosts ruminants production and reproduction
}

\author{
Imtiaz Hussain Raja Abbasi' ${ }^{1}$ Farzana Abbasi ${ }^{2}$, Lamei Wang ${ }^{1}$, Mohamed E. Abd El Hack ${ }^{3}$, Ayman A. Swelum4,
} Ren $\mathrm{HaO}^{1}$, Junhu $\mathrm{YaO}^{1}$ and Yangchun $\mathrm{CaO}^{1 *}$

\begin{abstract}
Folate has gained significant attention due to its vital role in biological methylation and epigenetic machinery. Folate, or vitamin $\left(B_{9}\right)$, is only produced through a de novo mechanism by plants and micro-organisms in the rumen of mature animals. Although limited research has been conducted on folate in ruminants, it has been noted that ruminal synthesis could not maintain folate levels in high yielding dairy animals. Folate has an essential role in one-carbon metabolism and is a strong antiproliferative agent. Folate increases DNA stability, being crucial for DNA synthesis and repair, the methylation cycle, and preventing oxidation of DNA by free radicals. Folate is also critical for cell division, metabolism of proteins, synthesis of purine and pyrimidine, and increasing the de novo delivery of methyl groups and S-adenosylmethionine. However, in ruminants, metabolism of $\mathrm{B}_{12}$ and $\mathrm{B}_{9}$ vitamins are closely connected and utilization of folate by cells is significantly affected by $B_{12}$ vitamin concentration. Supplementation of folate through diet, particularly in early lactation, enhanced metabolic efficiency, lactational performance, and nutritional quality of milk. Impaired absorption, oxidative degradation, or deficient supply of folate in ruminants affects DNA stability, cell division, homocysteine remethylation to methionine, de novo synthesis of S-adenosylmethionine, and increases DNA hypomethylation, uracil misincorporation into DNA, chromosomal damage, abnormal cell growth, oxidative species, premature birth, low calf weight, placental tube defects, and decreases production and reproduction of ruminant animals. However, more studies are needed to overcome these problems and reduce enormous dietary supplement waste and impaired absorption of folate in ruminants. This review was aimed to highlight the vital role of folic acid in ruminants performance.
\end{abstract}

Keywords: Epigenetic, DNA stability, Folate, Microbial methylation, Ruminants, Vitamin $B_{12}$

\section{Introduction}

An inappropriate balance of essential nutrients in the diet promotes health disorders and impedes the development of dairy animals. Bacterial populations in the rumen of ruminants synthesize a large amount of B vitamins and these essential nutrients are also supplemented

\footnotetext{
*Correspondence: caoyangchun@126.com

${ }^{1}$ Department of Animal Nutrition and Feed Science, College of Animal Science and Technology, Northwest A\&F University, Yangling 712100, Shaanxi, People's Republic of China

Full list of author information is available at the end of the article
}

in rations aimed to cover the needs of the animals and prevent deficiency disorder. However, the amounts of B vitamins in these rations are not adequate to achieve the best performance of high-yield dairy animals (Rosenblatt and Fenton 2001; Abbasi et al. 2014; Li et al. 2016). Folate $\left(\mathrm{C}_{19} \mathrm{H}_{19} \mathrm{~N}_{7} \mathrm{O}_{6}\right.$; folic acid or vitamin $\left.\mathrm{B}_{9}\right)$ has many forms, namely, folic acid (synthetic form) (Berry et al. 2010), methyltetrahydrofolate, folinic acid, methenyltetrahydrofolate, folacin, tetrahydrofolic acid, pteroyl-L-glutamate, and in the body, the liver acts as a major storage place for folates stored in the form of polyglutamates (Darby and 
jones 1945; Fenech 2012). In recent years, folate has come into focus due to its protective role, its essential role in metabolism, and because it is a key agent in de novo processes and epigenetics. Folate is important for hematopoiesis and function of red, white and new blood cells. Folate is also vital for biochemical functions in mammals including one-carbon methyl transfer reactions, the synthesis of purine, RNA, pyrimidine, and DNA by methylation, preventing changes in the DNA and abnormal cell development (Blount et al. 1997; Choi and Mason 2000; Kronenberg et al. 2008; Figueiredo et al. 2009), gene expression, and neurotransmitter functions (Ghoshal et al. 2006; Pogribny et al. 2008). Furthermore, folate contributes significantly to amino acids synthesis (Fournier et al. 2002; Shinohara et al. 2006), and is an important agent in the formation of the primary methylating agent, $S$-adenosylmethionine (SAM) (Bailey and Gregory 1999; Linhart et al. 2008). Folate plays an especially important role during the cells division cycle, growth, and the early gestation period (Kamen 1997). Ingredients which contain low folate along with an excessive number of unstable forms of this vitamin making analysis of dietary folate very interesting in ruminant animals.

Defective or impaired folate transportation or metabolism, resulting folate shortage and consequent 5-methyltetrahydrofolate depletion occurs (Rosenblatt and Fenton 2001). It was noted that, in most species, ingested folic acid rapidly reduced and methylated across the gastrointestinal wall before appearing as 5-methyl-tetrahydrofolate (5-methyl-THF) in the liver (LeGrusse et al. 1993). This cycle is irrevocable and a methyl group is released during conversion of 5-methyl-THF to homocysteine for use in methionine and tetrahydrofolate (THF) synthesis (Bassler 1997). THF is an active form of folate and functions as an acceptor of one-carbon units from multiple reactions (Xue and Snoswell 1985). However, methionine requirements in ruminants increase during lactation and methionine production is maintained through remethylation. This is because lactation duration increases the need for methylated agents (choline, creatine, creatinine, and carnitine), and methionine is needed to promote milk protein synthesis and production (Abbasi et al. 2017). However, net absorption or methylated agents is low and meeting the need for these methylated compounds requires de novo synthesis (Snoswell and Xue 1987) from gluconeogenic precursors, glycine or serine, the primary sources for the required methyl groups (Armentano 1994). During early lactation, glucose synthesis increases and this may generate a scarcity of resources for the de novo synthesis of methylated precursors. Under such a condition, without additional sources of methyl groups including methionine, which further metabolizes into homocysteine and cysteine, methyl donor deficiency results in poor milk protein or yield performance (Scott 1999; Abbasi et al. 2018). Furthermore, when methionine supply in dairy cow rations is low (NRC 2001), folic acid supplementation promotes better milk performance and proper methylation (Girard et al. 1995; Girard and Matte 1998; Smith et al. 2012). These studies suggest that during parturition, dietary folate requirements increase and folic acid synthesized by rumen microflora from rumen unprotected folate did not fulfill the needs of the animal. Folate deficiency first established in erythrocytes cells and then in bone marrow due to deficiency of RNA and DNA for normal cell division processes and subsequent protein/enzyme synthesis deficiency causing premature birth, low calf weight, and increased placental tube deformation risk (Blom et al. 2006; Gabory et al. 2011). However, folic acid supplementation through rations supplied methionine for anabolic output and enhanced efficiency of one-carbon units transfer (Wallingford et al. 2013). A satisfactory supply of methyl group sources or cofactors (folates, $\mathrm{B}_{12}$ ) promotes the different metabolic pathways and improves milk production. Therefore, the present review was undertaken to asses and elucidates the interactions and vital role of folic acid in ruminants performance.

\section{Metabolism of folate}

Almost all mammalian cells obtain 5-methyl-THF monoglutamate as exogenous folate, the kind of folate most commonly transported in the blood stream. In its natural form, folate occurs as polyglutamate in food ingredients. When this folate is digested, glutamate is removed in the rumen, and a methyl group is added and fascinated via cells. After methyl group activation, folate is available as folate coenzyme for DNA synthesis (Fowler 2001; Liu and Ward 2010). Furthermore, natural dietary folate possesses five to seven glutamate side chains residues linked by g-peptide linkages (Gregory 1996; Wallingford et al. 2013). In most species, dietary folate is absorbed via the small intestine and then moved to the liver, where it is metabolized into 5 -methyl-THF by dihydrofolate reductase and then polyglutamated for cellular retention (Stanger 2002; Liu and Ward 2010). Next, THF is converted to 5,10-methylene-THF through the vitamin $\mathrm{B}_{6}$ dependent serine hydroxymethyltransferase reaction before being reduced irrevocably into 5-methylTHF by methylenetetrahydrofolate reductase (MTHFR) enzyme. 5-Methyl-THF works as a co-substrate and a key methyl donor for methionine synthesis from homocysteine. Methionine has a key role and contributes SAM, which has a vital role in 5-methylcytosine forming methylation reactions catalyzed by DNA methyltransferases (DNMTs) (Stanger 2002; Liu and Ward 2010; Crider et al. 2012; Abbasi et al. 2018). In this pathway, 
key genes include those related to relocating the methyl group to homocysteine, such as those encoding methylenetetrahydrofolate (MTRR), reduced folate carrier (RFC), and vitamin $B_{12}$-dependent methionine synthase (MTR) (Zhang et al. 2013). However, 5-methyl-THF is a poor enzyme for elongating glutamate chains (Shane 1989), and vitamin $B_{12}$ is needed to enable elimination of the methyl group for methionine synthesis (Shane et al. 1977). It has been noted that demethylation of 5-methylTHF is a limiting reaction for cellular accretion of folates (Lucock 2007). The uptake of 5-methyl-THF by cells is maintained through transporters, namely, proton coupled folate transporter (PCFT) and reduced folate carrier (RFC). The receptors involved are folate receptor alpha (FRa) and folate receptor beta (Frb) (Matherly and Goldman 2003). Alteration or mutation can damage the gene coding PCFT and cause inherited folate malabsorption disorder (Zhao et al. 2007, 2009). Then PCFT plays a major role in intestinal folate absorption; when folate binds to PCFT receptors, it is taken up by epithelial cells through receptor-mediated endocytosis and from there, easily passes into the interstitium and cerebrospinal fluid of the brain (Blount et al. 1997; Wu and Pardridge 1999).

\section{Folate deficiency and genomic instability}

Folate has a dominant role in DNA metabolism, function, and repair due to its ability to methylate cytosine, thereby controlling gene expression, and its key function in nucleotide synthesis. Folate deficiency leads to genomic instability and genomic instability appears through two latent pathways (Fig. 1). The first pathway in which folate plays a significant role is altered DNA methylation. The major circulating folate type, 5-methyl-THF, acts as a cofactor in methionine synthesis (Abbasi et al. 2018). Methionine is converted to SAM methylates, the main methyl donors in DNA cytosine methylation, and methylation controls gene expression. Under folate deficiency, SAM is depleted, and methyltransferase activity is elevated, leading to DNA hypomethylation (Yi et al. 2000), insufficient proto-oncogene activation, transcription, and subsequent growth of abnormal cells or tumors (Kim et al. 1996; Fang and Xiao 2001). Proper folate concentration is important for the synthesis of DNA nucleotides, the backbone of DNA, in which desoxyuridylate monophosphate (dUMP) is changed to thymidylate monophosphate (TMP) by thymidylate synthase using 5,10-methyleneTHF as a methyl donor. When folate is low, dUMP may fold and start inducing uracil misincorporation.

The second pathway by which folate deficiency modifies genomic stability position. This occurs when vitamin $\mathrm{B}_{12}$ is restrictively low and 5-methyl-THF cannot undergo further metabolization to yield THF. Consequently, the availability of 5,10-methylene-THF decreases, and less is available to maintain methylation reactions. However, folate, as 5,10-methylene-THF, donates a methyl group to uracil, converting it to thymine for DNA synthesis and repair. If folate concentration is limiting, uracil misincorporation increases and genomic instability develops. This condition develops as cells of the body attempt to repair themselves, breaking DNA molecules to remove uracil. When folate concentration is limited, the precursor pool of deoxynucleotide triphosphates is reduced, and misincorporation of uracil increases in "a catastrophic repair cycle" which may promote double-strand breaks, chromosomal damage, and abnormal cell growth (Fig. 1) (Reidy 1988; Blount and Ames 1994). Furthermore, a study reported that low folate may induce malignant transformation, declining SAM biosynthesis, de novo thymidine monophosphate synthesis, modified gene expression by defective cytosine methylation, or lead to the development of catastrophic cycles of aberrant DNA repair and subsequently uracil misincorporation (Ciappio and Mason 2010). Folate deficiency also promotes purine biosynthesis and increased DNA hypomethylation disorder (Kim et al. 1996; Duthie and Hawdon 1998). Specifically, when folate concentration in the body is balanced, there is reduced uracil misincorporation, inhibition of DNA excision repair, DNA stability increases, and growth of abnormal cells is limited (Duthie et al. 2000).

\section{Methylation cycle and the potential role of folate}

Methylation is a key reaction cycle through which a methyl group is transferred on to, enzymes, amino acids, proteins, and DNA in cells or tissue to control healing processes, cell energy, DNA expression, neurological function, liver detoxification, and immunity (Kim et al. 2009; Yang et al. 2010). Methylation occurs chemically or biologically. In chemical methylation, a methyl group is added or substituted on to a substrate. In biological methylation, the reaction is catalyzed by enzymes; this kind of methylation is mostly involved in the alteration of heavy metals, gene expression regulation, protein function, and DNA and RNA processing. Gene expression regulation mechanisms in which gene expression or function is altered without any change to the DNA sequence (e.g. DNA methylation) are the key processes underlying epigenetics. These mechanisms are essential for regular growth and related to a number of key processes including: genomic imprinting, $\mathrm{X}$-chromosome inactivation, suppression of identical elements, the aging process, and carcinogenesis (Lister et al. 2009; Rana and Ankri 2016). Epigenetics is the study of phenotypic variations that arise without the underlying DNA sequence being altered (Suzuki and Bird 2008; Fazzari and Greally 2010; Colaneri et al. 2011). Epigenetic methylation processes are significantly affected by dietary levels of 


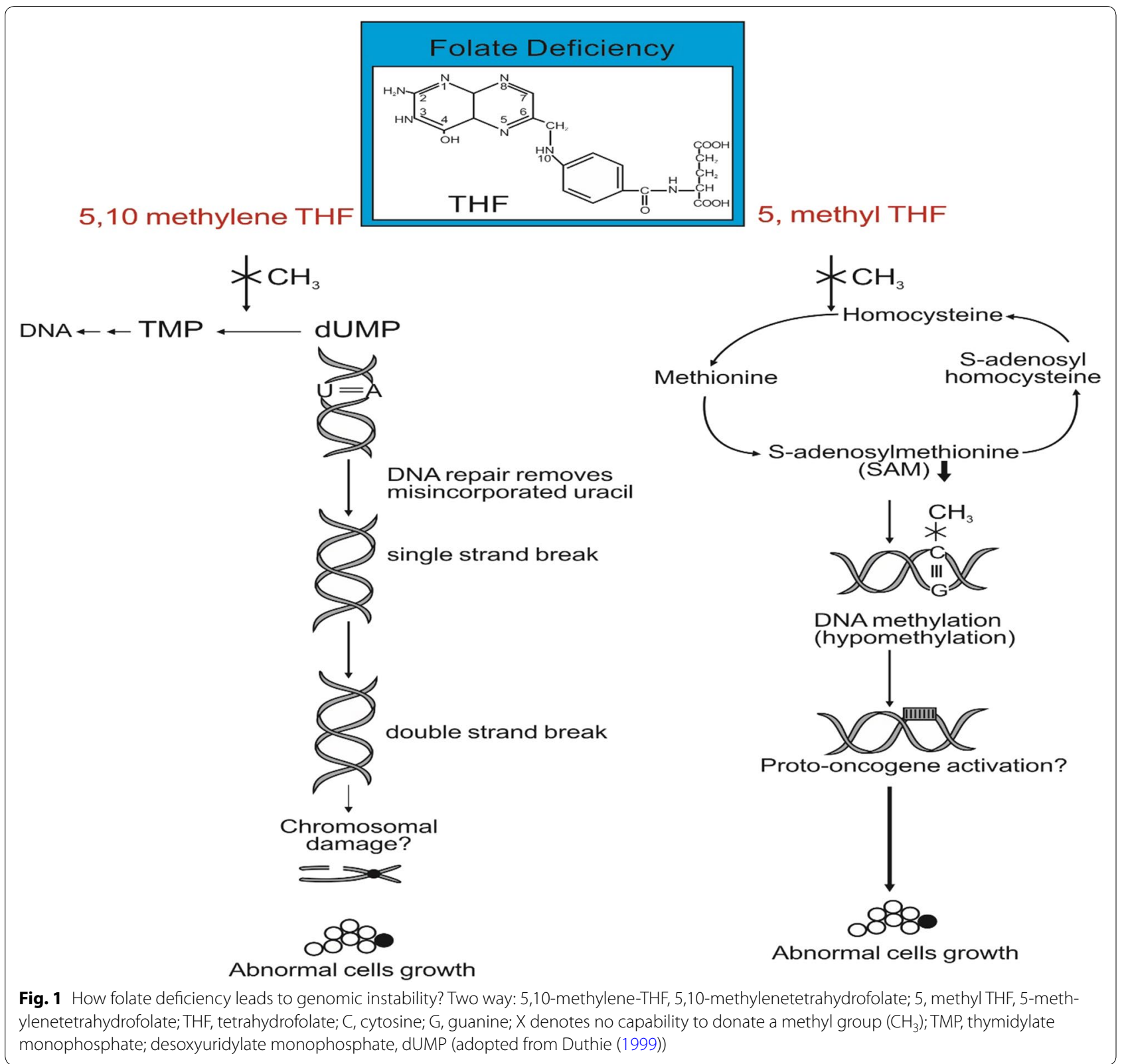

methyl donors, namely folate and its derivatives: THF, 10-formyl-THF, 5-formyl-THF, and 5-methyl-THF. Dietary folic acid is primarily metabolized into 5-methylTHF after intestinal absorption. 5-Methyl-THF then passes through the liver, is reduced to dihydrofolate by dihydrofolate reductase, and then further reduced to THF before entering the folate pool. 5-Methyl-THF is the primary folate constituent carried by non-hepatic tissues, and must be polyglutamated for cellular retention and one carbon cycle coenzyme function (Rowling et al. 2002; Lucock 2007). THF is mainly produced by the action of folate polyglutamate synthetase, and secondarily produced by the conversion of 5-methylTHF to THF through methionine metabolism. In rare situations where dihydrofolate reductase is high, folic acid is oxidized and present in the circulation system in its active form (Bailey et al. 2010). When the THF coenzyme is formed from either folic acid or dietary folate, it first changes in to 5,10-methylene-THF catalyzed by vitamin $\mathrm{B}_{6}$-dependent serine hydroxymethyltransferase, before being irrevocably reduced by methylenetetrahydrofolate reductase (MTHFR) into 5-methyl-THF (Fig. 2) (Scott 1999). Vitamin $B_{12}$-dependent methionine synthase balances the fluctuation of methyl groups for 


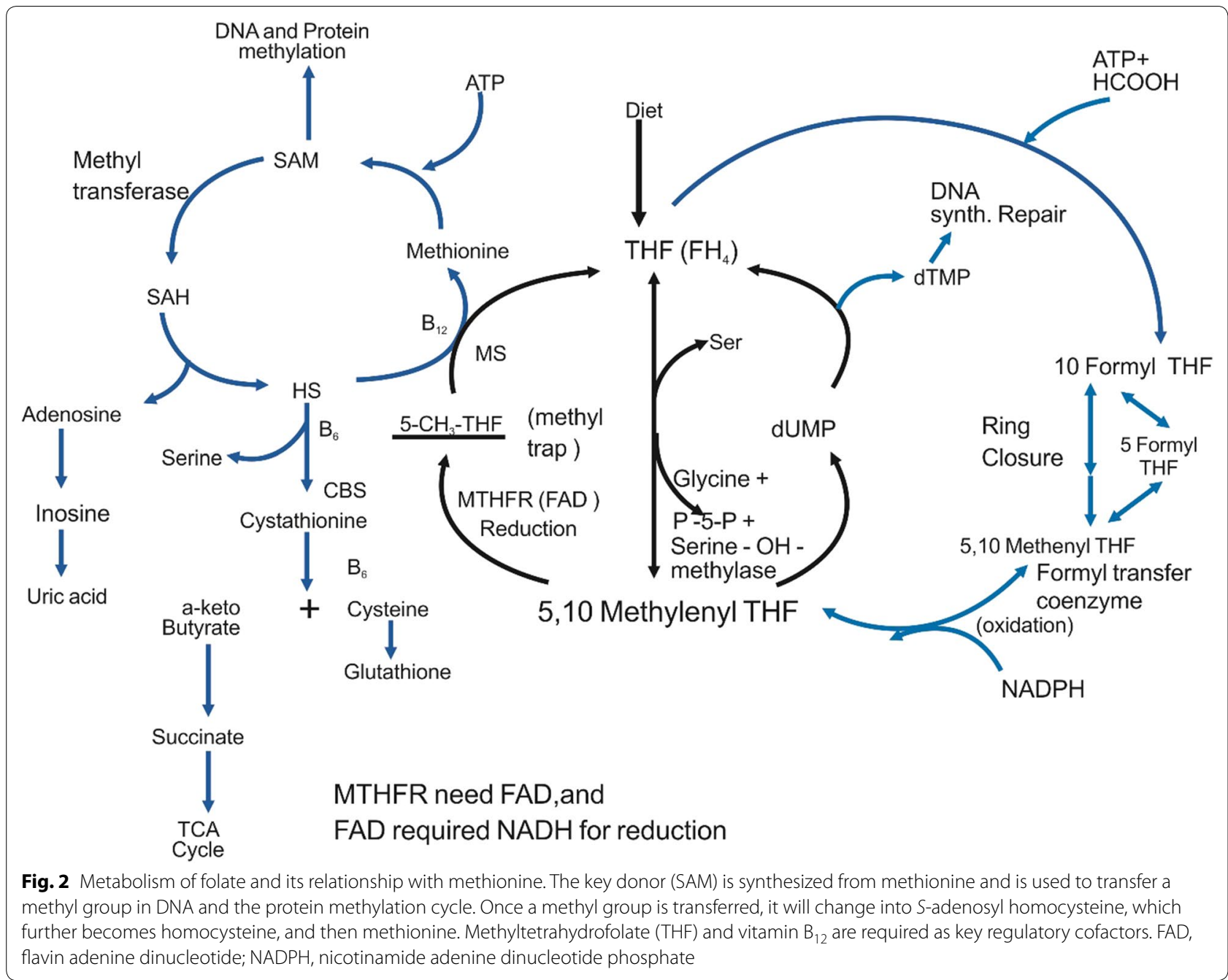

remethylation of homocysteine to yield methionine and regulate $S$-adenosyl methionine synthesis. Methionine is also a methyl donor for and a cofactor in the methylation of DNA, RNA, neurotransmitters, histones, phospholipids, proteins, and other small molecules (Fig. 2) (Stover 2009). Several reactions are regulated by SAM and SAM concentration significantly affects gene transcription, genomic stability (Miranda and Jones 2007), protein localization (Winter-Vann et al. 2003), and small molecule degradation (Stead et al. 2004). DNA methylation controlling gene transcription and genetic stability is one of the most important types of reactions among the more than a hundred methylation reactions (enzymatic) mediated by SAM. However, with folate, several other dietary nutrients are required to balance one-carbon flux. For example, serine from dietary and microbial sources plays a significant role in one-carbon flux as it donates two one-carbon units as it is converted into glycine before being catabolized further (LeGrusse et al. 1993).
Moreover, de novo serine synthesis using glycerophosphate as a substrate transfers a methyl group in to the one-carbon pool (Emmanuel and Kennelly 1984; Armentano 1994). Other important nutrients that play a key role in methylation reactions include: vitamin $B_{6}$ (serine hydroxymethyltransferase activity), riboflavin (MTHFR stability), vitamin $B_{12}$ (methionine synthase function), and choline (betaine precursor, homocysteine methyltransferase) (Combs 1998; Shin et al. 2010; Abbasi et al. 2017). If the concentration of SAM is high, MTHFR is inhibited, due to the synthesis of 5-methyl-THF and remethylation of homocysteine is reduced. Vice versa, when SAM is low, homocysteine remethylation is increased. Therefore, MTHFR activity and formation of 5-methylTHF may mitigate the effect of the common genetic variant, 677C/T, which decreases enzymatic activity (Bailey 2009). However, S-adenosylhomocysteine (SAH) works as a strong product inhibitor of SAM-dependent methyltransferase (Hoffman et al. 1980; Finkelstein 1990). Due 
to the fact that hydrolysis of SAH into homocysteine is required for DNA methylation (James et al. 2002), demethylation of 5-methyl-THF does not occur if vitamin $\mathrm{B}_{12}$ is too low (Bassler 1997). Even if folate concentration is adequate, a shortage of vitamin $B_{12}$ inhibits the production of methionine and SAM (Rowling et al. 2002; Reed et al. 2004). Insufficient availability of folate during cell division reduces the synthesis of thymidine, increases uracil misincorporation, and hampers DNA repair. Insufficient folate can decrease the capacity of cells to restore DNA under oxidative or alkylation conditions (Duthie et al. 2000) and therefore, impedes cell proliferation. This mutagenic condition may have negative effects including a higher frequency of chromosomal breaks and abnormal cell growth (Lamprecht and Lipkin 2003).

\section{Folates and vitamin $B_{12}$ interaction}

Vitamin $B_{12}$ plays an important and significant role in the metabolism of homocysteine and methionine; $\mathrm{B}_{12}$ and folate promote remethylation of homocysteine which in turn allows for methionine synthesis. However, homocysteine is also converted into cysteine (a precursor of glutathione) through actions of cystathionine- $\beta$-synthase and cystathionase enzymes. Ruminal bacteria of mature animals have the ability to synthesize $B$ vitamins using folic acid and $B_{12}$ vitamin (Lardinois et al. 1944; NRC 2001) for their use and use by the host organism. B vitamins production is important, because B vitamins act as cofactors or coenzymes for the breakdown and absorption of fatty acids, proteins, non-structural or structural carbohydrates, and genomic material (Combs 2012). It has been noted in many studies that B vitamins supplements can promote methionine synthesis, the remethylation cycle, milk production and improved composition, and metabolic efficiency of high yielding ruminants (Shaver and Bal 2000; Graulet et al. 2007). All B-vitamins, folate, and folic acid (pteroyl-L-glutamic acid) are beneficial nutrients for optimum productivity in dairy animals, but vitamin $B_{12}$ is an especially key agent in folate metabolism. Although vitamin $B_{12}$ is synthesized by rumen bacteria and archaea, synthesis is also dependent on cobalt concentration (Martens et al. 2002; Abbasi et al. 2013). Furthermore, two major vitamin $\mathrm{B}_{12}$-dependent enzymes are present in dairy animals, methionine synthase and second methylmalonyl-CoA mutase. Methionine synthase transfers a methyl group from 5-methyl-THF to homocysteine to yield methionine and THF. However, methylmalonyl-CoA mutase transforms methylmalonylCoA into succinyl-CoA for utilization in the Krebs cycle reaction and then, the gluconeogenesis process. A study found vitamin $B_{12}$ concentrations in dairy cows serum to be $2.4,2.0$ and $1.2 \mathrm{ng} / \mathrm{ml}$ at 21,7 and 120 days after parturition (McDowell 2000). Vitamin $B_{12}$ level declined from
21 to 7 days prepartum (Kincaid et al. 2003). Furthermore, another study using multiparous cows, presented that vitamin $B_{12}$ concentration significantly decreased in serum from $5.7 \mathrm{ng} / \mathrm{ml}$ at 55 days prepartum to 2.3, 2.0 and $1.9 \mathrm{ng} / \mathrm{ml}$ at 20,7 and 120 days after parturition respectively (Kincaid and Socha 2007). Synthesis of $\mathrm{B}_{12}$ and folic acid in the rumen of dairy cattle has been measured to be 73.0-79.8 and $16.5-21.0 \mathrm{mg} /$ day respectively (Santschi et al. 2005; Schwab et al. 2006), and these rates of synthesis significantly affect the amount of vitamins secreted into milk (Ferlay et al. 2013). Some studies reported that vitamin $\mathrm{B}_{12}$ deficiency is sometimes mitigated by high folate concentration (Selhub et al. 2009), and that vitamin $B_{12}$ secretion into the milk can be managed in dairy animals through dietary supplementation of vitamin $B_{12}$. It has been recorded that milk contains highly variable concentrations of vitamin $B_{12}$ among different farms, with the normal range fluctuating from 2.2 to $3.9 \mathrm{ng} / \mathrm{ml}$ (Duplessis 2014). In studies that supplemented diets with folic acid, folic acid utilization decreased in cows tissues in early lactation due to vitamin $B_{12}$ deficiency and because folic acid was trapped in serum in its methylated form, which significantly inhibits demethylation. Current knowledge suggests that methionine synthesis is dependent on vitamin $B_{12}$ enabling the conversion of extracellular 5-methyl-THF into polyglutamate THF, which is utilized in nucleotide synthesis, and that therefore, folate and vitamin $B_{12}$ levels should be managed in rations (Sirotnak and Tolner 1999; Chassaing et al. 2011). Moreover, during catabolism of homocysteine, serum folate concentration was noted to be higher with the production of cysteine, and vitamin $B_{12}$ concentration was low. However, methionine and serum clearance of folate was improved in multiparous cattles when fed folic acid with rumen-protected methionine supplementation, suggesting that vitamin $B_{12}$ synthesis and supply was inadequate and inhibited folate production (Girard et al. 2005). Thus, vitamin $B_{12}$ may be a limiting factor for folic acid metabolism in dairy animals (Girard and Matte 1998).

\section{The folic acid requirement, supplementation, and performance of dairy ruminants}

During lactation and gestation in high-producing dairy animals, methylneogenesis, DNA synthesis, cell division, epigenetic processes, and others important processes deeply depend on folate metabolism. While a supply of nucleic acids from microbial digestion might reduce the burden on the DNA cycle, gluconeogenesis and methylneogenesis is high in high-producing dairy animals, particularly during early lactation (Abbasi et al. 2018). However, in some cases, precursors of de novo synthesis of methylated compounds were found to be insufficient. 
In these cases, folate supplementation would improve the transport of one-carbon units. Consequently, a supply of both co-factors (folate and $\mathrm{B}_{12}$ ) and methyl donors were essential for maximum dairy performance. Some studies reported that, in growing steers, duodenum folate concentrations were marginal, and non-gestating cattle had serum folate concentrations greater than that of gestating cattle (Arbeiter and Winding 1973; Tremblay et al. 1991). In dairy cows, total serum folate level was noted to decline by about $40 \%$ within the 2 months prior to a calving (Girard et al. 1989). Changes in serum folate concentration provide signs as to the relationship between folate supply and folate utilization in tissues and the change in that relationship during different physiological stages. Folic acid supplementation increased the placental and colostral transmission of folate to the calf. Other effects on blood hemoglobin, growth, birth weight, and feed intake of the mother were not found to be significant during the 10 weeks prior to birth. Other studies reported that folic acid injection promotes a significant increase in milk protein content in multiparous cows, but has no significant effect in primiparous cows (Girard et al. 1995; Girard and Matte 1998). Folate and vitamin $\mathrm{B}_{12}$ concentrations in plasma increased during dietary supplementation of both nutrients (Girard and Matte 2005). However, during dietary supplementation of cobalt, vitamin $B_{12}$ serum level during early lactation was lower in primiparous cattles than in multiparous cattles (Girard and Matte 1999). This study also reported that in early lactation in dairy cows, serum vitamin $B_{12}$ concentration was lower, but serum folate concentration peaked, particularly during folic acid dietary supplementation. However, the situation was reversed 8-12 weeks after lactation, when serum vitamin $B_{12}$ was higher than serum folate in supplemented cows (Girard and Matte 1999). Previous studies reported that folic acid is also synthesized by ruminal micro-organisms, but folic acid from ruminal-synthesis is about $16.5-21.0 \mathrm{mg} /$ day (Santschi et al. 2005), less than the folic acid requirement estimated recommended for dairy cows by the National Research Council (35 mg/day) (NRC 2001). Furthermore, ruminal microorganisms degrade around $>0.95$ of supplemented folic acid in dairy cows rations (Santschi et al. 2005). Thus, rumen-protected folic acid (RPFA) is necessary for high-producing ruminants.

Folic acid is required by ruminal microorganisms (Girard et al. 1994; Wejdemar 1996), and dietary supplementation of folic acid has been shown to increase cellulolytic bacterial population (Wejdemar 1996), cellulose digestion (Ragaller et al. 2010), ruminal fermentation (Hayes et al. 1966), ammonia nitrogen $\left(\mathrm{NH}_{3}-\mathrm{N}\right)$ utilization (Wejdemar 1996), and concentration of milk yield, or milk protein (Girard et al. 1995; Girard and Matte
1998). However, other studies found that ruminal fermentation (Chiquette et al. 1993; Girard et al. 2009) and $\mathrm{NH}_{3}-\mathrm{N}$ utilization (Girard et al. 1994; Ragaller et al. 2010) were not changed by supplementary folic acid. Another study reported that with increasing dietary crude protein (CP) and RPFA supplementation, ruminal total volatile fatty acid (VFA) concentration in dairy animals was consistent with degradability, bacterial population size, and microbial enzymatic action (Broderick 2003; Wang et al. 2016). Ruminal pH was lower in steers under RFPA supplementation, and this was attributed to an increased ruminal total VFA concentration, urinary total purine derivative excretion, and ruminal $\mathrm{NH}_{3}-\mathrm{N}$ utilization for microbial protein synthesis (Froetschel et al. 1989; Wang et al. 2016; Kolver and Deveth 2002). Dietary supplementation of both CP and RPFA promoted microbial growth, increased microbial enzyme activity, increased in situ ruminal digestibility, and improved total VFA production in beef cattles (Wang et al. 2017). Supplementation of vitamin $\mathrm{B}_{9}$ and $\mathrm{B}_{12}$ improved the condition and performance of high-producing dairy cows, especially through the critical period around calving and early lactation (Preynat et al. 2009). Dietary supplementation of vitamins $B_{9}$ and $B_{12}$ together increased production of milk components and milk yield in dairy cows (Ouattara et al. 2016). Metabolic efficiency, dry matter intake, and milk performance were increased with supplementation of folic acid in dairy cattles, but plasma glucose and hepatic lipids decreased when dairly cattles were fed vitamin $B_{12}$ together with folic acid (Graulet et al. 2016). Folic acid and $B_{12}$ vitamin supplementation resulted in an approximately $12 \%$ increase in milk yield in multiparous cows between 3 weeks before calving and 16 weeks of lactation (Preynat et al. 2010). Some studies found that populations of $R$. albus, $R$. flavefaciens, B. fibrisolvens, and $F$. succinogene and the activity of cellobiase, xylanase, pectinase, and $\alpha$-amylase increased quadratically with increasing PRFA supplementation. Furthermore, overall fiber degradability increased by $42 \%$ and in vitro and in situ ruminal acid detergent fiber degradability increased when rations were supplemented with folic acid (Wang et al. 2016). Studies on dairy cows reported a supplemented folic acid dose of $2 \mathrm{mg} / \mathrm{kg} \mathrm{BW}$ (body weight) (Girard et al. 1994), 3-6 mg/kg BW (Girard et al. 2009), approximately $1.65 \mathrm{mg} / \mathrm{kg} \mathrm{BW}$ (Ragaller et al. 2010), and $0.2 \mathrm{mg} / \mathrm{kg}$ BW (Wang et al. 2017).

In conclusion, folic acid (Folate) supplementation offers a therapeutic for hematological, immunological, oxidative, and genomic complications, increases 5-methyltetrahydrofolate levels, and promotes the synthesis of milk protein from dietary protein in ruminants. It is imperative to adjust ruminants folate requirements precisely and according to the stage and physiological period. 
More the study is needed concerning whether supplementation of folate in rations should be rumen-protected or rumen-unprotected. More research is also necessary for developing nutritional policies that promote vitamin synthesis by ruminal microflora and for finding the balance between supply and demand of folic acid in ruminants rations.

\section{Abbreviations}

DNMTs: DNA methyltransferases; dUMP: desoxyuridylate monophosphate; Fra: folate receptor alpha; Frb: folate receptor beta; MTHFR: methylenetetrahydrofolate reductase; MTRR: methylenetetrahydrofolate; PCFT: proton coupled folate transporter; RFC: reduced folate carrier; SAM: S-adenosylmethionine; THF: tetrahydrofolate; TMP: thymidylate monophosphate.

\section{Authors' contributions}

Professor YCC and JHY conceived the idea, reviewed, and supervised the study. AlHR reviewed the literature and wrote the manuscript. MEAEH and AAS critically read, revised, and improved the article, while AF and $\mathrm{RH}$ supplied materials and designed figures. All authors read and approved the final manuscript.

\section{Author details}

1 Department of Animal Nutrition and Feed Science, College of Animal Science and Technology, Northwest A\&F University, Yangling 712100 Shaanxi, People's Republic of China. ${ }^{2}$ School of Life Science and Engineering, Southwest University of Science and Technology, Mianyang 621010, Sichuan, People's Republic of China. ${ }^{3}$ Department of Poultry, Faculty of Agriculture, Zagazig University, Zagazig 44511, Egypt. ${ }^{4}$ Department of Animal Production, College of Food and Agriculture Sciences, King Saud University, P.O. Box 2460, Riyadh 11451, Saudi Arabia.

\section{Acknowledgements}

Author (Abbasi IHR) would like to thanks Professor Cao Yangchun for his ideas, guidance, and kind co-supervision of this Doctorate work.

\section{Competing interests}

The authors declare that they have no competing interests.

\section{Availability of data and materials}

Not applicable.

\section{Consent for publication}

Not applicable.

\section{Ethics approval and consent to participate} Not applicable.

\section{Funding}

This work was partially supported by the National Key Research and Development Program of China (Award Numbers: 2017YFD0500500), National Natural Science Foundation of China (Award Numbers: 31472122 and 31672451), Collaborative Innovation Major Project of Industry, University, Research and Application in Yangling Demonstration Zone (Award Numbers: 2016CXY-18).

\section{Publisher's Note}

Springer Nature remains neutral with regard to jurisdictional claims in published maps and institutional affiliations.

Received: 13 March 2018 Accepted: 13 April 2018

Published online: 23 April 2018

\section{References}

Abbasi IHR, Sahito HA, Abbasi F, Kalwar MA, Soomro AA, Menghwar DR (2013) Management and production of livestock and poultry through advance techniques in Sindh. Pak In J Inn Agr Biol Res 1(1):31-42

Abbasi IHR, Sahito HA, Abbasi F, Menghwar DR, Kaka NA, Sanjrani MI (2014) Impact of different crude protein levels on growth of lambs under intensive management system. Int J Adv Res 2:227-235

Abbasi IHR, Abbasi F, Soomro RN, Abd El-Hack ME, Abdel-Latif MA, Li W, Hao R, Sun F, Bodinga BM, Hayat K, Yao J (2017) Considering choline as methionine precursor, lipoproteins transporter, hepatic promoter and antioxidant agent in animals. AMB Expr 7:214

Abbasi IHR, Abbasi F, Abd El-Hack ME, Abdel-Latif MA, Soomro RN, Hayat K, Mohamed M, Bodinga BM, Yao J, Cao Y (2018) Critical analysis of excessive utilization of crude protein in ruminants ration: impact on environmental ecosystem and opportunities of supplementation of limiting amino acids-a review. Environ Sci Poll Res 25:181-190

Arbeiter VK, Winding W (1973) Folate best immungenim serum von rindernmitbesonderem bezug auf die fruchtbarkeit. Wien Tiera"rztl Monatsschr $60: 323-326$

Armentano LE (1994) Impact of metabolism by extra gastrointestinal tissues on secretory rate of milk proteins. J Dairy Sci 77:2809-2820

Bailey LB (2009) Folate in health and disease, 2nd edn. Taylor and Francis, Boca Raton, FL, pp 1-583

Bailey LB, Gregory JF (1999) Folate metabolism and requirements. J Nutr 129:779-782

Bailey RL, Mills JL, Yetley EA, Gahche JJ, Pfeiffer CM, Dwyer JT (2010) Unmetabolized serum folic acid and its relation to folic acid intake from diet and supplements in a nationally representative sample of adults aged $>$ or $=60$ years in the United States. Am J Clin Nutr 92:383-389

Bassler KH (1997) Enzymatic effects of folic acid and vitamin $B_{12}$. Int J Vit Nutr Res 67:385-388

Berry RJ, Bailey L, Mulinare J, Bower C (2010) Fortification of flour with folic acid. Food Nutr Bull 31:S22-S35

Blom HJ, Shaw GM, Den Heijer M, Finnell RH (2006) Neural tube defects and folate: case far from closed. Nat Rev Neurosci 7:724-731

Blount BC, Ames BN (1994) Analysis of uracil in DNA by gas chromatographymass spectometry. Anal Biochem 219:195-200

Blount BC, Mack MM, Wehr CM, MacGregor JT, Hiatt RA, Wang G (1997) Folate deficiency causes uracil misincorporation into human DNA and chromosome breakage: implications for cancer and neuronal damage. Proc Natl Acad Sci USA 94:3290-3295

Broderick GA (2003) Effects of varying dietary protein and energy levels on the production of lactating dairy cows. J Dairy Sci 86:1370-1381

Chassaing C, Graulet B, Agabriel C, Martin B, Girard CL. Vitamin B and B contents in cow milk according to production system. In: Coppa M, Borreani $G$ (eds). Proceedings of the 10th international meeting on mountain cheese. Dronero, Italy, 14-15 September 2011; p. 35-6

Chiquette J, Girard CL, Matte JJ (1993) Effect of diet and folic acid addition on digestibility and ruminal fermentation in growing steers. J Anim Sci 71:2793-2798

Choi SW, Mason JB (2000) Folate and carcinogenesis: an integrated scheme. J Nutr 130:129-132

Ciappio E, Mason JB (2010) Folate and carcinogenesis: basic mechanisms. In: Bailey LB (ed) Folate in health and disease, 2nd edn. CRC Press, Boca Raton, pp 235-262

Colaneri A, Staffa N, Fargo DC, Gao Y, Wang T, Peddada SD (2011) Expanded methyl-sensitive cut counting reveals hypomethylation as an epigenetic state that highlights functional sequences of the genome. Proc Natl Acad Sci USA 108:9715-9720

Combs JRGF (1998) The vitamins: fundamental aspects in nutrition and health, 2nd edn. Academic Press, San Diego

Combs GF (2012) The vitamins, 4th edn. Elsevier Inc., San Diego

Crider KS, Yang TP, Berry RJ, Bailey LB (2012) Folate and DNA methylation: a review of molecular mechanisms and the evidence for folate's role. Adv Nutr 3:21-38

Darby WJ, Jones E (1945) Treatment of sprue with synthetic L. casei factor (folic acid, vitamin M). Exp Biol Med 60(2):259-262

Duplessis M (2014) Impact d'un supplement combine d'acidefolique et de vitamine $B_{12}$ enperiodeprepartum et en debut de la lactation chez la vachelaitiere. Ph.D. thesis. University Laval, Quebec, QC, Canada

Duthie SJ (1999) Folic acid and DNA stability. Br Med Bull 55:578-592 
Duthie SJ, Hawdon A (1998) DNA instability (strand breakage, uracil misincorporation, and defective repair) is increased by folic acid depletion in human lymphocytes in vitro. FASEB J 12:1491-1497

Duthie SJ, Narayanan S, Blum S, Pirie L, Brand G (2000) Folate deficiency in vitro induces uracil misincorporation and DNA hypomethylation and inhibits DNA excision repair in immortalised normal human colon epithelial cells. Nutr Cancer 37:245-251

Emmanuel B, Kennelly JJ (1984) Kinetics of methionine and choline and their incorporation into plasma lipids and milk components in lactating goats. J Dairy Sci 67:1912-1918

Fang JY, Xiao SD (2001) Alteration of DNA methylation in gastrointestinal carcinogenesis. J Gastroenterol Hepatol 16:960-968

Fazzari MJ, Greally JM (2010) Introduction to epigenomics and epigenome wide analysis. Methods Mol Biol 620:243-265

Fenech M (2012) Folate (vitamin $B_{9}$ ) and vitamin $B_{12}$ and their function in the maintenance of nuclear and mitochondrial genome integrity. Mutat Res 733(1-2):21-33

Ferlay A, Graulet B, Chilliard Y (2013) Maitrise par I'alimentation des teneursenacidesgras et en composes vitaminiques du lait de vache. INRA Prod Anim 26:177-192

Figueiredo JC, Grau MV, Haile RW (2009) Folic acid and risk of prostate cancer: results from a randomized clinical trial. J Natl Cancer Inst 101(6):432-435

Finkelstein JD (1990) Methionine metabolism in mammals. J Nutr Biochem 1:228-237

Fournier I, Ploye F, Cottet EJM, Brun J, Claustrat B (2002) Folate deficiency alters melatonin secretion in rats. J Nutr 132:2781-2784

Fowler B (2001) The folate cycle and disease in humans. Kidney Int Suppl 78:5221-5229

Froetschel MA, Amos HE, Evans JJ, Croom WJ, Hagler JR (1989) Effects of a salivary stimulant, slaframine, on ruminal fermentation, bacterial protein synthesis and digestion in frequently fed steers. J Anim Sci 67:827-834

Gabory A, Attig L, Junien C (2011) Developmental programming and epigenetics. Am J Clin Nutr 94:1943S-1952S

Ghoshal K, Li X, Datta J, Bai S, Pogribny I, Pogribny M (2006) A folate- and methyl-deficient diet alters the expression of DNA methyltransferases and methyl $\mathrm{CpG}$ binding proteins involved in epigenetic gene silencing in livers of F344 rats. J Nutr 136:1522-1527

Girard CL, Matte JJ (1998) Dietary supplements of folic acid during lactation: effects on the performance of dairy cows. J Dairy Sci 81:1412-1419

Girard CL, Matte JJ (1999) Changes in serum concentrations of folates, pyridoxal, pyridoxal-5-phosphate and vitamin $\mathrm{B}_{12}$ during lactation of dairy cows fed dietary supplements of folic acid. Can. J Anim Sci 79:107-113

Girard CL, Matte JJ (2005) Effects of intramuscular injections of vitamin $B_{12}$ on lactation performance of dairy cows fed dietary supplements of folic acid and rumen-protected methionine. J Dairy Sci 88:671-676

Girard CL, Matte JJ, Tremblay GF (1989) Serum folates in gestating and lactating dairy cows. J Dairy Sci 72:3240-3246

Girard CL, Chiquette J, Matte JJ (1994) Concentrations of folates in ruminal content of steers: responses to a dietary supplement of folic acid in relation with the nature of the diet. J Anim Sci 72:1023-1028

Girard CL, Matte JJ, Tremblay GF (1995) Gestation and lactation of dairy cows: a role for folic acid? J Dairy Sci 78:404-411

Girard CL, Lapierre H, Matte JJ, Lobley GE (2005) Effects of dietary supplements of folic acid and rumen-protected methionine on lactational performance and folate metabolism of dairy cows. J Dairy Sci 88:660-670

Girard CL, Benchaar C, Chiquette J, Desrochers A (2009) Net flux of nutrients across the rumen wall of lactating dairy cows as influenced by dietary supplements of folic acid. J Dairy Sci 92:6116-6122

Graulet B, Matte JJ, Desrochers A, Doepel L, Palin MF, Girard CL (2007) Effects of dietary supplements of folic acid and vitamin $B_{12}$ on metabolism of dairy cows in early lactation. J Dairy Sci 90(7):3442-3455

Graulet B, Matte JJ, Desrochers A, Doepel L, Palin MF, Girard CL (2016) Effects of dietary supplements of folic acid and vitamin $B_{12}$ on metabolism of dairy cows in early lactation. J Dairy Sci 90:3442-3455

Gregory JF (1996) Vitamins. In: Fennema OR (ed) Food chemistry. Marcel and Dekker, New York, pp 590-600

Hayes BW, Mitchell GE, Little CO, Bradley NW (1966) Concentrations of B-vitamins in ruminal fluid of steers fed different levels and physical forms of hay and grain. J Anim Sci 25:539-542
Hoffman DR, Marion DW, Cornatzer WE, Duerre JA (1980) S-Adenosylmethionine and S-adenosylhomocysteine metabolism in isolated rat liver. Effects of L-methionine, L-homocysteine, and adenosine. J Biol Chem 255:10822-10827

James SJ, Melnyk S, Pogribna M, Pogribny IP, Caudill MA (2002) Elevation in S-adenosylhomocysteine and DNA hypomethylation: potential epigenetic mechanism for homocysteine-related pathology. J Nutr 132:2361S-2366S

Kamen B (1997) Folate and antifolate pharmacology. Semin Oncol 24(5 Suppl 18):S-18-30-S-18-39

Kim YI, Pogribny LP, Salomon RN, Choi SW, Smith DE, James SJ (1996) Exonspecific DNA hypomethylation of the $p 53$ gene of rat colon induced by dimethylhydrazine: modulation by dietary folate. Am J Pathol 149:1129-1137

Kim JK, Samaranayake M, Pradhan S (2009) Epigenetic mechanisms in mammals. Cell Mol Life Sci 66:596-612

Kincaid RL, Socha MT (2007) Effect of cobalt supplementation during late gestation and early lactation on milk and serum measures. J Dairy Sci 90:1880-1886

Kincaid RL, Lefebvre LE, Cronrath JD, Socha MT, Johnson AB (2003) Effect of dietary cobalt supplementation on cobalt metabolism and performance of dairy cattle. J Dairy Sci 86:1405-1414

Kolver ES, Deveth MJ (2002) Prediction of ruminal pH from pasture-based diets. J Dairy Sci 85:1255-1266

Kronenberg G, Harms C, Sobol RW, Cardozo PF, Linhart H, Winter B (2008) Folate deficiency induces neurodegeneration and brain dysfunction in mice lacking uracil DNA glycosylase. J Neurosci 28:7219-7230

Lamprecht SA, Lipkin M (2003) Chemoprevention of colon cancer by calcium, vitamin D and folate: molecular mechanisms. Nat Rev Cancer 3:601-614

Lardinois CC, Mills RC, Elvehjem CA, Hart EB (1944) Rumen synthesis of the vitamin B complex as influenced by ration composition. J Dairy Sci 27:579-583

LeGrusse J, Watier B (1993) Les vitamines. Donne'esbiochimiques, nutritionnelles et cliniques. Centre d'e'tude et d'information sur les vitamines, Produits Roche. Neuilly-sur-Seine, France

Li HQ, Liu Q, Wang C, Yang ZM, Guo G, Huo WJ (2016) Effects of dietary supplements of rumen-protected folic acid on lactation performance, energy balance, blood parameters and reproductive performance in dairy cows. Anim Feed Sci Technol 213:55-63

Linhart HG, Troen A, Bell GW, Cantu E, Chao WH, Moran E (2008) Folate deficiency induces genomic uracil misincorporation and hypomethylation but does not increase DNA point mutations. Gastroenterology 136:227-235

Lister R, Pelizzola M, Dowen RH, Hawkins RD, Hon G, Tonti FJ (2009) Human DNA methylomes at base resolution show widespread epigenomic differences. Nature 462:315-322

Liu JJ, Ward RL (2010) Folate and one-carbon metabolism and its impact on aberrant DNA methylation in cancer. Adv Genet 71:79-121

Lucock M (2007) Folic acid: nutritional biochemistry, molecular biology, and role in disease processes. Mol Genet Metab 1:121-138

Martens JH, Barg H, Warren M, Jahn D (2002) Microbial production of vitamin $B_{12}$. Appl Microbiol Biotechnol 58:275-285

Matherly LH, Goldman DI (2003) Membrane transport of folates. Vitam Horm 66:403-456

McDowell LR (2000) Vitamins in animal and human nutrition, 2nd edn. lowa State University Press, Ames

Miranda TB, Jones PA (2007) DNA methylation: the nuts and bolts of repression. J Cell Physiol 213:384-390

NRC (2001) Nutrient requirements of dairy cattle, 6th edn. National Academy of Sciences, Washington, DC

Ouattara B, Nathalie B, Melissa D, Christiane LG (2016) Supplements of vitamins $B_{9}$ and $B_{12}$ affect hepatic and mammary gland gene expression profiles in lactating dairy cows. BMC Genom 17:640

Pogribny IP, Karpf AR, James SR, Melnyk S, Han T, Tryndyak VP (2008) Epigenetic alterations in the brains of Fisher 344 rats induced by long-term administration of folate/methyl-deficient diet. Brain Res 1237:25-34

Preynat A, Lapierre H, Thivierge MC, Palin MF, Matte JJ, Desrochers A (2009) Effects of supplements of folic acid, vitamin $B_{12}$, and rumen-protected methionine on whole-body metabolism of methionine and glucose in lactating dairy cows. J Dairy Sci 92:677-689 
Preynat A, Lapierre H, Thivierge MC, Palin MF, Cardinault N, Matte JJ (2010) Effects of supplementary folic acid and vitamin $B_{12}$ on hepatic metabolism of dairy cows according to methionine supply. J Dairy Sci 93:2130-2142

Ragaller V, Lebzien P, Bigalke W, Sudekum KH, Huther I, Flachowsky G (2010) Effects of folic acid supplementation to rations differing in the concentrate to roughage ratio on ruminal fermentation, nutrient flow at the duodenum, and on serum and milk variables of dairy cows. Arch Anim Nutr 64:484-503

Rana AK, Ankri S (2016) Reviving the RNA world: an insight into the appearance of RNA methyltransferases. Front Genet 7:99

Reed MC, Nijhout HF, Sparks R, Ulrich CM (2004) A mathematical model of the methionine cycle. J Theor Biol 226:33-43

Reidy JA (1988) Role of deoxyuridine incorporation and DNA repair in the expression of human chromosomal fragile sites. Mutat Res 211:215-220

Rosenblatt DS, Fenton WA (2001) Inherited disorders of folate and cobalamin transport and metabolism. In: Scriver CR, Beaudet AL, Sly WS, Valle D (eds) The metabolic and molecular bases of inherited disease, vol 3, 8th edn. McGraw-Hill, New York, pp 897-933

Rowling MJ, McMullen MH, Chipman DC, Schalinske KL (2002) Hepatic glycine $\mathrm{N}$-methyltransferase is up-regulated by excess dietary methionine in rats. J Nutr 132:2545-2550

Santschi DE, Berthiaume R, Matte JJ, Mustafa AF, Girard CL (2005) Fate of supplementary B-vitamins in the gastrointestinal tract of dairy cows. J Dairy Sci 88:2043-2054

Schwab EC, Schwab CG, Shaver RD, Girard CL, Putnam DE, Whitehouse NL (2006) Dietary forage and non-fiber carbohydrate contents influence B-vitamin intake, duodenal flow, and apparent ruminal synthesis in lactating dairy cows. J Dairy Sci 89:174-187

Scott JM (1999) Folate and vitamin B 12 . Proc Nutr Soc 58:441-448

Selhub J, Morris MS, Jacques PF, Rosenberg IH (2009) Folate-vitamin $B_{12}$ interaction in relation to cognitive impairment, anemia, and biochemical indicators of vitamin $\mathrm{B}_{12}$ deficiency. Am J Clin Nutr 89:702S-706S

Shane B (1989) Folylpolyglutamate synthesis and role in the regulation of onecarbon metabolism. Vitam Horm 45:263-335

Shane B, Watson JE, Stockstad ELR (1977) Uptake and metabolism of (3H) folate by normal and by vitamin B-12 and methionine-deficient rats. Biochim Biophys Acta 497:241-252

Shaver RD, Bal MA (2000) Effect of dietary thiamin supplementation on milk production by dairy cows. J Dairy Sci 83:2335-2340

Shin W, Yan J, Abratte CM, Vermeylen F, Caudill MA (2010) Choline intake exceeding current dietary recommendations preserves markers of cellular methylation in a genetic subgroup of folate-compromised men. J Nutr 140:975-980

Shinohara Y, Hasegawa H, Ogawa K, Tagoku K, Hashimoto T (2006) Distinct effects of folate and choline deficiency on plasma kinetics of methionine and homocysteine in rats. Metabolism 55:899-906

Sirotnak FM, Tolner B (1999) Carrier-mediated membrane transport of folates in mammalian cells. Annu Rev Nutr 19:91-122

Smith ZD, Chan MM, Mikkelsen TS, Gu H, Gnirke A, Regev A (2012) A unique regulatory phase of DNA methylation in the early mammalian embryo. Nature 484:339-344
Snoswell AM, Xue GP (1987) Methyl group metabolism in sheep. Comp Biochem Physiol 88B:383-394

Stanger O (2002) Physiology of folic acid in health and disease. Curr Drug Metab 3:211-223

Stead LM, Jacobs RL, Brosnan ME, Brosnan JT (2004) Methylation demand and homocysteine metabolism. Adv Enzyme Regul 44:321-333

Stover PJ (2009) One-carbon metabolism-genome interactions in folate associated pathologies. J Nutr 139:2402-2405

Suzuki MM, Bird A (2008) DNA methylation landscapes: provocative insights from epigenomics. Nat Rev Genet 9:465-476

Tremblay GF, Girard CL, Bernier CM, Matte JJ (1991) Nycterohemeral variations of concentration of serum folates in dairy cows. Can J Anim Sci 71:919-923

Wallingford JB, Niswander LA, Shaw GM, Finnell RH (2013) The continuing challenge of understanding, preventing, and treating neural tube defects. Science 339:122-202

Wang C, Liu Q, Guo G, Huo WJ, Ma L, Zhang YL (2016) Effects of dietary supplementation of rumen protected folic acid on rumen fermentation, degradability and excretion of urinary purine derivatives in growing steers. Arch Anim Nutr 70:441-454

Wang C, Liu Q, Guo G, Huo WJ, Liang CY, Pei X (2017) Effects of different dietary protein levels and rumen-protected folic acid on ruminal fermentation, degradability, bacterial populations and urinary excretion of purine derivatives in beef steers. J Agric Sci 155(9):1477-1486

Wejdemar K (1996) Some factors stimulating the growth of butyrivibrio fibrisolvens TC33 in clarified rumen fluid. Swedish J Agric Res 26:11-18

Winter-Vann AM, Kamen BA, Bergo MO, Young SG, Melnyk S, James SJ (2003) Targeting Ras signaling through inhibition of carboxyl methylation: an unexpected property of methotrexate. Proc Natl Acad Sci USA 100:6529-6534

Wu D, Pardridge WM (1999) Blood-brain barrier transport of reduced folic acid. Pharm Res 16:415-419

Xue GP, Snoswell AM (1985) Regulation of methyl group metabolism in lactating ewes. Biochem Int 11:381-385

Yang X, Lay F, Han H, Jones PA (2010) Targeting DNA methylation for epigenetic therapy. Trends Pharmacol Sci 31:536-546

Yi P, Melnyk S, Pogribna M, Pogribny IP, Hine RJ, James SJ (2000) Increase in plasma homocysteine associated with parallel increases in plasma S-adenosyl homocysteine and lymphocyte DNA hypomethylation. J Biol Chem 275(38):29318-29323

Zhang T, Lou J, Zhong R, Wu J, Zou L, Sun Y (2013) Genetic variants in the folate pathway and the risk of neural tube defects: a meta-analysis of the published literature. PLOS ONE 8:e59570

Zhao R, Min SH, Qiu A, Sakaris A, Goldberg GL, Sandoval C (2007) The spectrum of mutations in the PCFT gene, coding for an intestinal folatetransporter, that are the basis for hereditary folate malabsorption. Blood 110:1147-1152

Zhao R, Min SH, Wang Y, Campanella E, Low PS, Goldman ID (2009) A role for the proton-coupled folate transporter (PCFTSLC46A1) in folate receptor-mediated endocytosis. J Biol Chem 284:4267-4274

\section{Submit your manuscript to a SpringerOpen ${ }^{\odot}$ journal and benefit from:}

- Convenient online submission

- Rigorous peer review

- Open access: articles freely available online

- High visibility within the field

- Retaining the copyright to your article

Submit your next manuscript at springeropen.com 